\title{
Heavy Metals Content in Paraphilometroides nemipteri from South China Sea may Influence Level of Glutathione and P38 Protein Expression
}

(Kandungan Logam Berat dalam Paraphilometroides nemipteri dari Laut China Selatan Boleh Mempengaruhi Tahap Glutation dan Ekspresi Protein P38)

\author{
Nurul Huda ABD KADIR*, MOHD FAuZi MAHMUd, MOHAMAD KHAIRI MOHD ZAINOL, \\ MASTURA ABD MALEK \& FAIZAH SHAHAROM HARRISON
}

\begin{abstract}
Numerous studies have shown that parasites potentially become bio-accumulators for heavy metals. The heavy metals content in parasite-infected fish was reported to be lower compared to the parasite non-infected fish. Evaluation of heavy metal content in Nemipterus peronii and Paraphilometroides nemipteri was performed using ICP-OES. Our result has shown that arsenic was the most abundance heavy metal content in muscle $\mathrm{N}$. peronii and $\mathrm{P}$. nemipteri, suggesting that the parasite has the ability to accumulate heavy metals. Heavy metals were reported to induce oxidative stress where glutathione and 38 protein may be involved. Thus, expression of the p38 protein was determined using western blot technique and glutathione content was measured fluorometrically. The p38 expression in P. nemipteri of Pulau Kambing was higher compared to P. nemipteri of Besut has shown that the parasite may exposed to stress. Glutathione content showed no significant changes due to detoxification mechanism occurred in the parasite. In this study, we could conclude that $\mathrm{P}$. nemipteri could be a bio-accumulator, whereas p38 protein and glutathione as indicator of stress level in the parasite that exposed to the heavy metals.
\end{abstract}

Keywords: Glutathione; heavy metals, Nemipterus peronii; oxidative stress; Paraphilometroides nemipteri

\section{ABSTRAK}

Banyak kajian telah menunjukkan bahawa parasit berpotensi menjadi bio-akumulator bagi logam berat. Kandungan logam berat dalam ikan yang dijangkiti parasit dilaporkan lebih rendah berbanding ikan parasit yang tidak dijangkiti parasit. Penilaian kandungan logam berat dalam Nemipterus peronii dan Paraphilometroides nemipteri dilakukan menggunakan ICP-OES. Keputusan yang diperoleh menunjukkan bahawa arsenik merupakan kandungan logam berat yang paling banyak di dalam otot $\mathrm{N}$. peronii dan P. nemipteri, ini menunjukkan bahawa parasit mempunyai keupayaan untuk mengumpul logam berat. Logam berat dilaporkan menyebabkan tekanan oksidatif dengan protein glutation dan p38 mungkin terlibat. Oleh itu, ekspresi protein p38 ditentukan dengan menggunakan teknik Western blot dan kandungan glutation diukur secara fluorometri. Ekspresi protein p38 oleh P. nemipteri dari Pulau Kambing adalah lebih tinggi berbanding P. nemipteri di Besut, menunjukkan bahawa parasit mungkin terdedah kepada tekanan. Kandungan glutation tidak menunjukkan perubahan ketara disebabkan oleh mekanisme detoksifikasi yang berlaku pada parasit. Dalam kajian ini, kita dapat menyimpulkan bahawa P. nemipteri boleh menjadi bio-akumulator melalui ekspresi protein p38 dan glutation sebagai penunjuk aras tekanan dalam parasit yang terdedah kepada logam berat.

Kata kunci: Glutation; logam berat; Nemipterus peronii; Paraphilometroides nemipteri; tekanan oksidatif

\section{INTRODUCTION}

Heavy metals are known as one of the main contributors to aquatic pollution (Palaniappan \& Karthikeyan 2009) and are considered as critical contaminants of aquatic ecosystems (Jarić et al. 2011). Industrial wastes, geochemical structure and mining of metals create a potential source of heavy metal pollution in the aquatic environment (Gümgüm et al. 1994; Karadede \& Ünlü 2000; Lee \& Stuebing 1990). Fish and other aquatic organisms were reported accumulating heavy metals from polluted sea water (Kumar et al. 2012). A study conducted by Saliu and Bawa-Allah (2012) has shown that high concentration of Manganese (Mn), Cadmium $(\mathrm{Cd})$, Lead $(\mathrm{Pb})$, Mercury $(\mathrm{Hg})$ and Copper $(\mathrm{Cu})$ were found accumulated in the liver, intestine, heart and gills of the fish. Furthermore, Kamaruzzaman et al. (2011) and Rejomon et al. (2010) have reported that the heavy metals can be found in Nemipterus japonicus from South China Sea. In this study, we have chosen Pulau Kambing and Besut, which are situated along South China Sea as our sampling sites. Pulau Kambing is located at the adjunction of Sungai Nerus and Sungai Terengganu, which highly contaminated due to human activities in this populated area (Chee et al. 2008). On the other hand, Sungai Besut is considered to be low contaminant site, due to less populated area and has been reported as clean (Suratman et al. 2006).

P38 mitogen-active protein kinase (MAPKs) is known as stress indicator and usually invoved in stressresponse cell signalling that will affected by natural 
and unnatural stimuli, for example redox change, uv light, hyperosmolarity, growth, death, migratory signal (Ressurreição et al. 2011). In the past decade, parasites in fish has been discovered to posses an ability in accumulating heavy metals from the fish (host) (Sures et al. 1999) and environment (Zimmermann et al. 1999). Numerous researches have reported that parasites in fish could be bio-accumulators of heavy metals (Brázová et al. 2012; Hassan et al. 2016; Mazhar et al. 2014) due high heavy metals content in the parasites compare to host (fish). The findings lead to a speculation that the parasites have an ability to accumulate the heavy metals in their body. However, toxicological mechanisms of heavy metals accumulation in the parasites are not well studied.

The metals may induce oxidative stress that results in imbalance of reactive oxygen species (ROS) production when antioxidant enzymes activity changed (Nishida 2011). The antioxidant enzymes such as superoxide dismutase (SOD), catalase (CAT), glutathione peroxidase (GPX) and glutathione S-transferases (GSTs) are involved in defense mechanism against xenobiotics and heavy metals (Stohs \& Bagchi 1995). There are two types of heavy metals which are redox active metals and metals without redox (Sevcikova et al. 2011). Redox active metals induced oxidative stress by altering redox cycling in the cells, which leads to glutathione reduction and elevation of antioxidant enzymes such as SOD, CAT and GPX. On the other hand, metals without redox potential such as arsenic, cadmium, mercury, lead and selenium, may inhibits antioxidant defenses that caused glutathione fluctuation against time of exposure and affecting SOD and CAT activities (Valko et al. 2005).

Glutathione (GSH) is a non-thiol protein that present in most living cells and has been shown to play numerous roles, such as protection against oxidative stress, detoxification, transport and enzymatic catalysis that involve GSTs and GPX (Kim et al. 2005). Heavy metals also could affect the glutathione level in fish as demonstrated by Canesi et al. (1999), which the level of GSH were decreased in contaminated fish compared to non-heavy metals fish when heavy metal was accumulated in the fish tissues. Furthermore, GSH was found to be responsible in inducing toxicity by mutating glutamylcyteine synthetase, which involve in GSH synthesis that leads to oxidative stress in worms (Liao \& Yu 2005). Helmcke and Aschner (2010) reported that GSH content elevated in acute exposure of methylmercury-treated worms, whilst the GSH level of chronic exposure worms was shown to be depleted. According to Wilhelm et al. (1997), intracellular glutathione is responsible as a regulator in inducing cellular stress response, including Jun $\mathrm{N}$-terminal protein kinases (JNK) and p38 kinase.

On the other hand, p38 MAPK acts as a signal transduction component of heavy metals stress that mediates redox stress component of signal induction pathway when exposed to heavy metals (Rios-Barrera et al. 2008). A review by Ventura-Lima et al. (2011), reported that arsenic in aquaporins could affect signalling pathways by activating proteins such as ERK2, p38 and JNK as demonstrated in mammals. In this study, we believed that parasites might undergo stress when they accumulate metals in their body. Thus, a comparison study was conducted using a molecular approach to determine glutathione and $\mathrm{p} 38$ protein expression as stress biomarkers P. nemipteri, a bio-accumulator of heavy metals in the $N$. peronii.

\section{MATERIALS AND METHODS}

\section{SAMPLING SITES}

Fish (Nemipterus peronii) were collected from Pulau Kambing Kuala Terengganu, Terengganu (coordinate $\left.05^{\circ} 12^{\prime} 60.00^{\prime \prime} \mathrm{N}, 4^{\circ} 21^{\prime} 7.00^{\prime \prime} \mathrm{E}\right)$ and Kuala Besut, Terengganu (Besut) (coordinate 5०49'52.032" N, $0^{\circ} 0$ '0" E) as shown in Figure 1. The fish samples were transported to the laboratory in an icebox and stored at $-80^{\circ} \mathrm{C}$ prior further analysis. Their standard length and weight were documented during dissection. The fish were identified morphologically according to Ambak et al. (2012) and were sorted through labeling or coding.

\section{CHEMICALS}

Arsenic, Manganese, Cadmium, Cromium and Lead were purchased from Merck, Germany and all other chemicals unless stated in the text were purchased from Sigma Aldrich, USA.

\section{HEAVY METAL ANALYSIS}

Each sample left was taken out and thawed in an icebox. The thawed samples $(6 \mathrm{~g})$ were then transferred in a veil tube for freeze-drying process. The lyophilized samples were ground and kept in $-80^{\circ} \mathrm{C}$. Hydrogen peroxide (1 $\mathrm{mL})$ and nitric acid $(7 \mathrm{~mL})$ were added in the ground samples $(0.2 \mathrm{~g})$. The mixtures in veil tubes were vortexed vigorously and then transferred to Teflon vessel before digested in microwave digester for $15 \mathrm{~min}$ at $200^{\circ} \mathrm{C}$. The digested samples were diluted with deionized water (15 $\mathrm{mL}$ ) for heavy metals analysis using ICPOES. Arsenic (As), Manganese (Mn), Cadmium (Cd), Cromium (Cr) and Lead $\mathrm{Pb}$ ) were prepared by adding $1 \%$ nitric acid to each of the heavy metals standards to reach final volume of $100 \mathrm{~mL}$ at concentrations of $0.8 \mathrm{ppm}, 1.6 \mathrm{ppm}, 2.4 \mathrm{ppm}, 3.2 \mathrm{ppm}$ and $4.8 \mathrm{ppm}$.

\section{GLUTATHIONE ANALYSIS}

The parasites $(100 \mathrm{mg})$ in triplicates were lysed using a RNA/protein purification kit (Macharey-Nagel, Germany). The supernatant from lysed samples were mixed with $6.5 \% 5$-sulfosalicylic acid $(160 \mu \mathrm{L})$ on ice for $20 \mathrm{~min}$ and centrifuged at $14,000 \mathrm{rpm}$ for $5 \mathrm{~min}$ at $4^{\circ} \mathrm{C}$. The supernatants were kept at $-80^{\circ} \mathrm{C}$ until required. The supernatant fraction was diluted 10 -fold with sodium phosphate buffer (100 mM, pH7.5) and $100 \mathrm{uL}$ used 
for the assay in 96 well plates. In each well, $33.4 \mu \mathrm{L}$ of $O$-phthaldialdehyde (OPA) was added and wells were covered to avoid light exposure, then incubated for $30 \mathrm{~min}$ at room temperature before fluorescence.

\section{PROTEIN EXTRACTION AND QUANTIFICATION}

Proteins from the samples $(100 \mathrm{mg})$ were extracted by using NucleoSpin ${ }^{\circledR}$ RNA/Protein (Macherey-Nagel) protocol. Protein concentrations of the samples were obtained from Bradford assay, based on the protocol given by Bio-Rad Protein Assay (Bio-Rad, USA).

\section{WESTERN BLOTTING}

The extracted protein samples $(0.06 \mu \mathrm{g})$ were separated using NuPAGE 4-12\% bris-tris gels (Novex, Life Technologies, USA) according to the manufacturer protocol (Pub Part No. IM-8042) and transferred onto PVDF membrane (Novex, Life Technologies, USA). PVDF membranes were incubated overnight with primary antibodies at $4^{\circ} \mathrm{C}$ followed by incubation with HRP-conjugated secondary antibodies for an hour at room temperature. The following antibodies were used for western blotting: p38 MAPK (D13E1) $\mathrm{XP}^{\circledR}$ Rabbit mAb (Cell Signaling) (1:1000 dilution, 0.5 $\mu \mathrm{g} / \mathrm{mL})$ and HRP-conjugated Goat anti-Rabbit IgG $(\mathrm{H}+\mathrm{L})$ Secondary Antibody (G-21234, 1:2000 dilution, $2 \mu \mathrm{g} / \mathrm{mL}$ ) for $\mathrm{p} 38$ protein expression. Mouse monoclonal anti- $\beta$ actin (AM4302, 1: 5,000 dilution, $0.02 \mu \mathrm{g} / \mathrm{mL}$ ) (Ambion, USA) and HRP-conjugated anti-mouse secondary antibodies (A16072, 1:2,200 dilution, $0.4545 \mu \mathrm{g} / \mathrm{mL}$ ) (Life Technologies, USA) were prepared for $\beta$-actin protein expression as loading controls. The image p38 protein bands were analysed by using image $\mathrm{J}$ software.

\section{STATISTICAL ANALYSIS}

GraphPad Prism 5.0 was used to determine $\mathrm{IC}_{50}$ value. Oneway analysis of variance followed by Dunnett's multiple comparison was performed using GraphPad Prism V 5.0 to determine significant differences between groups.

\section{RESULTS}

Heavy metal may not be decomposed by bacteria or other living organisms and it can be found everywhere (Tekaya et al. 2013). Some heavy metals such as iron, zinc, selenium is not dangerous and essential for living thing in small amount, however it may be hazardous if it is present in high concentration and some heavy metal was highly toxic in low concentration, such as cadmium, lead, arsenic, mercury and chromium (Bagal-Kestwal et al.2008). In this study, we measured heavy metals content in the muscle of $N$. peronii from two different areas (Pulau Kambing and Besut as illustrates in Figure 1) in order to determine the level of heavy metal contamination. Analysis of arsenic (As), manganese (Mn), cadmium $(\mathrm{Cd})$, cromium $(\mathrm{Cr})$ and lead $(\mathrm{Pb})$ content in muscle tissues of $N$. peronii from Pulau Kambing and Besut is shown in Figure 2. Our data has shown that arsenic $(23.07 \pm 2.78 \mathrm{mg} / \mathrm{g}$ ) was the most abundance, followed by chromium $(4.19 \pm 1.08 \mathrm{mg} / \mathrm{g})$, manganese $(3.50 \pm 0.77$ $\mathrm{mg} / \mathrm{g})$, cadmium $(0.124 \pm 0.009 \mathrm{mg} / \mathrm{g})$ and lead $(-1.35$ $\pm 0.316 \mathrm{mg} / \mathrm{g}$ ), respectively, in the fish muscle from Pulau Kambing compared to negligible content of all the heavy metals in the fish muscle from Besut. The results suggesting that Pulau Kambing is highly contaminated area compare to Besut.

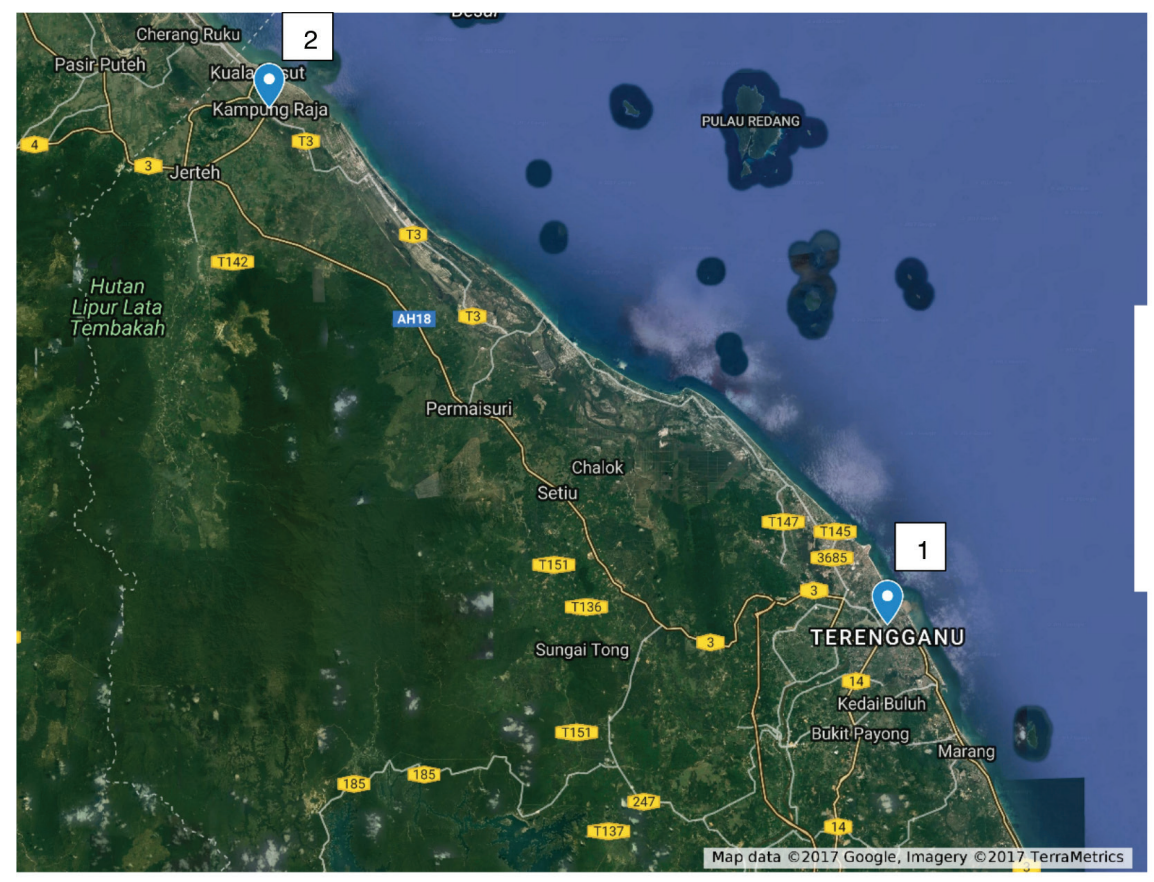

FIGURE 1. Sampling sites (1) Pulau Kambing, Kuala Terengganu (2) Besut, Kuala Terengganu 


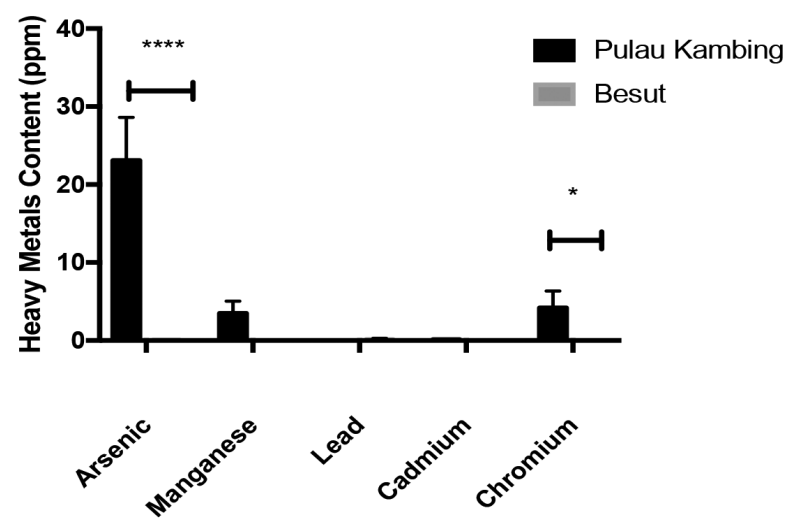

FIGURE 2. Arsenic, manganese, lead, cadmium, chromium content in muscle of N. peronii from Pulau Kambing and Besut, The heavy metal content was measured using ICP-OES. Statistical t test analysis was performed and $*$ indicate $p<0.05$, ** indicate $p<0.01$, *** indicate $p<0.001$ and $* * * *$ indicate $p<0.0001$ significant different of the metal concentration in fish muscle of Besut and Pulau Kambing areas. Data is presented as the mean $(n=3) \pm$ SEM

Table 1 shows the content of heavy metals in the muscle of $N$. peronii and its parasite, P. nemipteri from Pulau Kambing (high contaminated) and Kuala Besut (low contaminated). This comparison study of heavy metals in $N$. peronii muscle and P. nemipteri, has shown that all the heavy metals except chromium in the parasite was approximately 1.5 fold higher than the host (N.peronii) from Pulau Kambing, Similar trend could be seen for all other heavy metals content in P. nemipteri from Besut, which is approximately 1.5 fold higher than $N$. peronii muscle. The heavy metals level finding showed that the parasite (P.nemipteri) has the ability to accumulate heavy metals in their bodies.

Then, we carried out p38 protein and glutathione expression to determine physiological changes especially oxidative biomarkers of P. nemipteri, when they exposed to high and low contaminant areas. Based on our result (Figure 3), p38 protein bands were clearly expressed and the expression of the band was found to be higher in $P$. nemipteri from Pulau Kambing compared to Besut. The high p38 protein expression of $P$. nemipteri from Pulau Kambing compare to Besut was due to the higher level of heavy metals especially arsenic in Pulau Kambing than Besut, suggesting that the parasites might be exposed to oxidative stress.

GSH involve in detoxification and redox in organisms to encounter oxidative stress, thus we measured GSH content of the P. nemipteri from Pulau Kambing (high contaminant area) and Besut (low contaminant area). Based on our finding (Figure 4), negligible difference of the GSH content in the parasites from both Pulau Kambing and Besut.

\section{DISCUSSION}

High level of arsenic in the $N$. peronii muscle tissue and the fish muscle from Pulau Kambing has shown significance high level $(p<0.01)$ of arsenic content compared to Besut. Arsenic level which was found to be predominant in $N$. peronii muscle from Pulau Kambing suggesting that, the area is considered to be highly contaminated compare to Besut. According to Mazhar et al. (2014), arsenic was among the most concentrated heavy metals in muscles of $N$. peronii which was collected from Marang, Terengganu that is located along the South China Sea.

TABLE 1. Heavy metals content of $N$. peronii (fish/host) and P. nemipteri (parasite) from Pulau Kambing and Besut

\begin{tabular}{lcccc}
\hline & \multicolumn{2}{c}{ Pulau Kambing } & \multicolumn{2}{c}{ Besut } \\
\cline { 2 - 5 } & Fish muscles & Parasites & Fish muscles & Parasites \\
& $(\mathrm{N}=4 \pm \mathrm{SEM})$ & $(\mathrm{N}=4 \pm \mathrm{SEM})$ & $(\mathrm{N}=4 \pm \mathrm{SEM})$ & $(\mathrm{N}=4 \pm \mathrm{SEM})$ \\
\hline Arsenic & $23.07 \pm 2.78^{*}$ & $34.72 \pm 3.28^{*}$ & $0.037 \pm 0.0034^{*}$ & $0.0714 \pm 0.013^{*}$ \\
Manganese & $3.50 \pm 0.77^{*}$ & $4.99 \pm 0.476^{*}$ & $0.0093 \pm 0.0006$ & $0.0577 \pm 0.0298^{*}$ \\
Lead & $\mathrm{BDL}$ & $0.28 \pm 1.142$ & $\mathrm{BDL}$ & $\mathrm{BDL}$ \\
Cadmium & $0.124 \pm 0.009^{*}$ & $0.24 \pm 0.024$ & $0.0055 \pm 0.003$ & $0.00071 \pm 0.0004^{*}$ \\
Chromium & $4.19 \pm 1.08^{*}$ & $3.35 \pm 0.462$ & $0.096+0.005^{*}$ & $0.026 \pm 0.0078^{*}$ \\
\hline
\end{tabular}

The heavy metal content was measured using ICP-OES. Data is presented as the mean $(n=4) \pm$ SEM and one sample t-test was performed *Indicates data significant at $p<0.05$ and BDL is 'Below Detection Level' 
a) Pulau Kambing

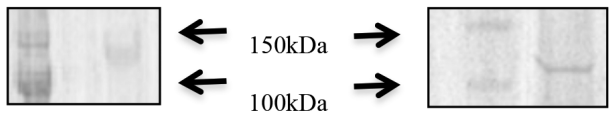

b)

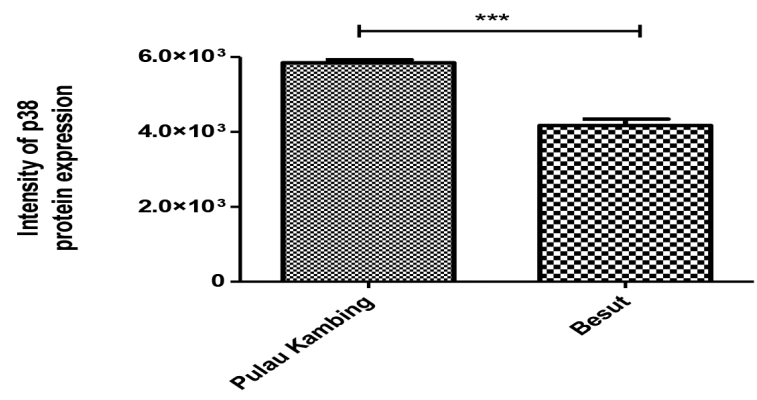

Data is presented as the mean $(n=3) \pm$ SEM. Statistical analysis was performed using t-test and the significant values are indicated as follows $* p<0.05$, ** $p<0.01$ and $* * * p<0.001$

FIGURE 3. a) Western blot band of p38 protein expression of Paraphilometroides nemipteri in Pulau Kambing and Besut, respectively and b) Intensity of $\mathrm{P} 38$ protein expression of Paraphilometroides nemipteri from Besut and Pulau Kambing was analysed using Image J software

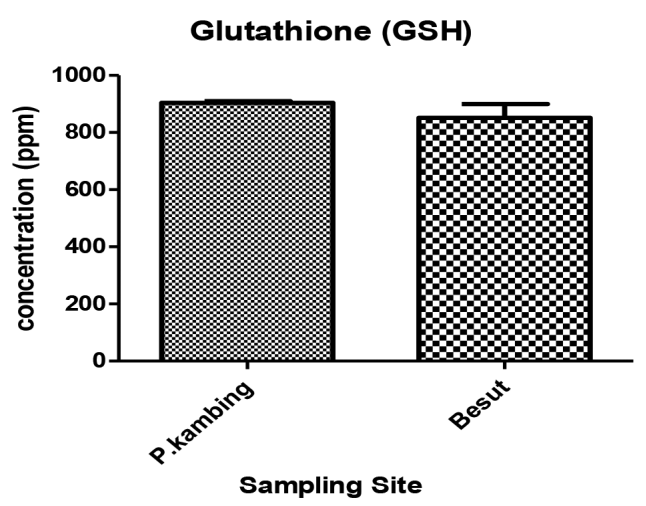

Statistical analysis (one way ANOVA, Dunnet post-test) was performed and * indicate $p<0.05$, ** indicate $p<0.01$ and $* * *$ indicate $p<0.001$ significant different of the glutathione concentration in Paraphilometroides nemipteri of Besut and Pulau Kambing areas. Data is presented as the mean $(n=3) \pm$ SEM

FIGURE 4. Glutathione content in Paraphilometroides nemipteri from Pulau Kambing and Besut. The glutathione content was measured fluorometrically

$P$. nemipteri is an ectoparasite that adheres and consumes blood that contains heavy metals, from the muscle of dorsal fins, ventral fins and operculum of $N$. peronii. According to Mazhar et al. (2014), P. nemipteri contain high content of arsenic compared to the host $(N$. peronii) due to their ability in absorbing heavy metals such as cadmium, lead, aluminium directly from the blood of the host. In addition, $P$. nemipteri also was found to accumulate toxic elements from the water as an additional route of heavy metals uptake in the nematode body (Zimmermann et al. 1999). Furthermore, a genomic study by Sahu et al. (2013) showed that genomic response of nematodes, Caenorhabditis elegans after the exposure with sodium arsenite exhibited oxidative stress response. Sahu et al. (2013) added that oxidative stress from arsenic as a result in production of ROS or the release of iron through induction of heme oxygenase. Oxidative stress, a pathological process relates to over-production of reactive oxygen species (ROS) in tissues and could be one of important general toxicity mechanism for many xenobiotics. Oxidative stress has shown to be induced after heavy metals exposure in fish (Farombi et al. 2007). Previous study by Farombi et al. (2007) also stated that alteration in the antioxidant enzymes, glutathione system and induction of lipid peroxidation reflects the presence of heavy metals. In addition, many organisms including fish have involved in xenobiotics metabolism mechanisms to counteract the impact of ROS and these include various antioxidant defense enzymes such as SOD, CAT and GSTs (Farombi et al. 2007).

Since heavy metals may causes oxidative stress to organisms when exposed to the chemicals and may cause a detrimental problem to the aquatic livings (Ercal et al. 2001), we conducted a molecular study using p38 protein expression to detect stress level of $P$. nemipteri after the exposure of heavy metals from the sea. Our results have shown that p38 protein and GSH content were elevated in P. nemipteri from Pulau Kambing due to high level of arsenic in host and the parasite itself.

A high amount of arsenic could lead to the oxidative stress (Labuda et al. 2005). According to Rios-Barrera et al. (2008), heavy metals such as cadmium and mercury exhibited p38 MAPK activity that mediates redox stress of the MAPKK signal pathways in Euglena gracilis. P38 MAPK pathways was discovered to be associated with apoptosis, stress responses and immunity (Johnson \& Lapadat 2002). Blackwell et al. (2015) showed that sodium arsenite or other oxidative stressors activated p38 kinase through phosphorylation process in C.elegans. On the other hand, a study by Wang et al. (2008) reported that cadmium-induced germline apoptosis of $C$. elegans via JNK and p38 MAPK signalling pathways. Hence, we believed that arsenic and cadmium which are classified as metals without redox potential induced stress through p38 MAPK signalling pathways, but underlying stress pathways of $P$. nemipteri after the heavy metals exposure is not fully understood. To address this problem, we measured glutahione (GSH) level in order to investigate the biochemical changes in P. nemipteri when it exposed to heavy metals.

Espinoza et al. (2012) stated that there are changes in fish GSTs activity and glutathione (GSH) level may loss in accordance with the presence of high level of heavy metals. This condition will lead to oxidative stress that arise through normal metabolic processes (Hayes \& Strange 2000). Thus, we speculated that GSH of $P$. nemipteri could be affected when they consume the blood that has been contaminated heavy metals from the 
host. However, our result has shown that no significant changes of GSH level in P. nemipteri from both high and low contaminant areas. The unchanged GSH content in the parasite from both high contaminant and low contaminant areas was due to redox hemeostasis of the parasite that may protect the parasite against oxidative stress. Elia et al. (2003) and Rana et al. (1996) found that GSH content was increased in liver and gill of fish after the exposure of mercury due to amino acid substrates such as glutamine, cysteine and glycine uptake to form GSH as protection against oxidative stress.

Furthermore, Bhattacharya and Bhattacharya (2007) reported that ratio of GSSG/GSH was found to be increased after 10 days of arsenic exposure in Indian catfish, Clarias batrachus. Whilst, Allen et al. (2004) mentioned that GSH levels in fish liver and kidney were fluctuated depending on days of the arsenic exposure. Based on previous finding, the induction of $\mathrm{p} 38$ protein expression explained the elevated concentration of GSH level of P. nemipteri from Pulau Kambing due to arsenic exposure. We also believed that the protection event might be occurred and some anti-oxidant enzymes such as GSTs, CAT and SOD could be affected. Further research should be carried out to investigate the expression of these proteins in order to enhance understanding mechanisms of action of the parasites after the exposure of heavy metals from the host.

Our results have shown that $\mathrm{p} 38$ protein and GSH content were elevated in $P$. nemipteri from Pulau Kambing due to high level of arsenic in host and the parasite itself. The biochemical toxicity changes might lead to a speculation that the parasite might be having an ability to detoxify the heavy metals in their body. A future study needs to be performed to explore this detoxification mechanism.

\section{ACKNOWLEDGEMENTS}

This research was funded by the Ministry of Higher Education (MOHE), Malaysia with grant (Trans-FRGS vot 59291). Special thanks to the staff of AQUATROP for their assistance.

\section{REFERENCES}

Allen, T., Singhal, R. \& Rana, S.V.S. 2004. Resistance to oxidative stress in a freshwater fish Channa punctatus after exposure to inorganic arsenic. Biological Trace Element Research 98(1): 63-72.

Ambak, M.A., Isa, M.M., Zakaria, M.Z. \& Ghaffar, M.A. 2012. Fishes of Malaysia. Terengganu: Penerbit UMT.

Bagal-Kestwal, D., Karve, M.S., Kakade, B.\& Pillai, V.K. 2008. Invertase inhibition based electrochemical sensor for the detection of heavy metal ions in aqueous system: Application of ultra-microelectrode to enhance sucrose biosensor's sensitivity. Biosensors and Bioelectronics 24(4): 657-664.

Bhattacharya,A.\& Bhattacharya, S. 2007. Induction of oxidative stress by arsenic in Clarias batrachus: Involvement of peroxisomes. Ecotoxicology and Environmental Safety 66(2): 178-187.
Blackwell, T.K., Steinbaugh, M.J., Hourihan, J.M., Ewald, C.Y. \& Isik, M. 2015. SKN-1/Nrf, stress responses, and aging in Caenorhabditis elegans. Free Radical Biology and Medicine 88(Part B): 290-301.

Brázová, T., Torres, J., Eira, C., Hanzelová, V., Miklisová, D. \& Šalamún, P. 2012. Perch and its parasites as heavy metal biomonitors in a freshwater environment: The case study of the Ružín Water Reservoir, Slovakia. Sensors 12(3): 3068-3081.

Canesi, L., Viarengo, A., Leonzio, C., Filippelli, M. \& Gallo, G. 1999. Heavy metals and glutathione metabolism in mussel tissues. Aquatic Toxicology 46(1): 67-76.

Chee, P.S., Suhaimi, S., Keat, C.C., Noor, A.M.S. \& Norhayati, M.T. 2008. Metal geochemistry of Nerus River, Terengganu. Malaysian Journal of Analytical Sciences 12(3): 593-599.

Elia,A.C., Galarini, R., Taticchi, M.I., Dörr,A.J.M. \& Mantilacci, L. 2003. Antioxidant responses and bioaccumulation in Ictalurus melas under mercury exposure. Ecotoxicology and Environmental Safety 55(2): 162-167.

Ercal, N., Gurer-Orhan, H. \& Aykin-Burns, N. 2001. Toxic metals and oxidative stress Part I: Mechanisms involved in metal-induced oxidative damage. Current Topics in Medicinal Chemistry 1(6): 529-539.

Espinoza, H.M., Williams, C.R. \& Gallagher, E.P. 2012. Effect of cadmium on glutathione S-transferase and metallothionein gene expression in coho salmon liver, gill and olfactory tissues. Aquatic Toxicology 110: 37-44.

Farombi, E., Adelowo, O. \& Ajimoko, Y. 2007. Biomarkers of oxidative stress and heavy metal levels as indicators of environmental pollution in African cat fish (Clarias gariepinus) from Nigeria Ogun River. International Journal of Environmental Research and Public Health 4(2): 158165.

Gümgüm, B., ünlü, E., Tez, Z. \& Gülsün, Z. 1994. Heavy metal pollution in water, sediment and fish from the Tigris River in Turkey. Chemosphere 29(1): 111-116.

Hassan, A.H., Al-Zanbagi, N.A. \& Al-Nabati, E.A. 2016. Impact of nematode helminthes on metal concentrations in the muscles of Koshar fish, Epinephelus summana, in Jeddah, Saudi Arabia. The Journal of Basic \& Applied Zoology 74: 56-61.

Hayes, J.D. \& Strange, R.C. 2000. Glutathione S-Transferase polymorphisms and their biological consequences. Pharmacology 61(3): 154-166.

Helmcke, K.J. \& Aschner, M. 2010. Hormetic effect of methylmercury on Caenorhabditis elegans. Toxicology and Applied Pharmacology 248(2): 156-164.

Jarić, I., Višnjić-Jeftić, Ž., Cvijanović, G., Gačić, Z., Jovanović, L., Skorić, S. \& Lenhardt, M. 2011. Determination of differential heavy metal and trace element accumulation in liver, gills, intestine and muscle of sterlet (Acipenser ruthenus) from the Danube River in Serbia by ICP-OES. Microchemical Journal 98(1): 77-81.

Johnson, G.L. \& Lapadat, R. 2002. Mitogen-activated protein kinase pathways mediated by ERK, JNK, and p38 protein kinases. Science 298(5600): 1911-1912.

Kamaruzzaman, B., Rina, Z., John, B.A. \& Jalal, K. 2011. Heavy metal accumulation in commercially important fishes of South West Malaysian coast. Research Journal of Environmental Sciences 5(6): 595-602.

Karadede, H. \& Ünlü, E. 2000. Concentrations of some heavy metals in water, sediment and fish species from the Atatürk 
Dam Lake (Euphrates), Turkey. Chemosphere 41(9): 13711376.

Kim, S.D., Moon, C.K., Eun, S.Y., Ryu, P.D. \& Jo, S.A. 2005. Identification of ASK1, MKK4, JNK, c-Jun, and caspase-3 as a signaling cascade involved in cadmium-induced neuronal cell apoptosis. Biochemical and Biophysical Research Communications 328(1): 326-334.

Kumar, B., Sajwan, K. \& Mukherjee, D. 2012. Distribution of heavy metals in valuable coastal fishes from North East Coast of India. Turkish Journal of Fisheries and Aquatic Sciences 12(1): 81-88.

Labuda, J., Bubnicova, K.K., Kovalova, L., Vanickova, M., Mattusch, J. \& Wennrich, R. 2005. Voltammetric detection of damage to DNA by arsenic compounds at a DNA biosensor. Sensors 5(6): 411-423.

Lee, Y.H. \& Stuebing, R.B. 1990. Heavy metal contamination in the River Toad, Bufo juxtasper (Inger), near a copper mine in East Malaysia. Bulletin of Environmental Contamination and Toxicology 45(2): 272-279.

Liao, V.H. \& Yu, C.W. 2005. Caenorhabditis elegans gcs-1 confers resistance to arsenic-induced oxidative stress. Biometals 18(5): 519-528.

Mazhar, R., Shazili, N.A. \& Harrison, F.S. 2014. Comparative study of the metal accumulation in Hysterothalycium reliquens (nematode) and Paraphilometroides nemipteri (nematode) as compared with their doubly infected host, Nemipterus peronii (Notched threadfin bream). Parasitology Research 113(10): 3737-3743.

Nishida, Y. 2011. The chemical process of oxidative stress by copper(II) and iron(III) ions in several neurodegenerative disorders. Monatshefte für Chemie - Chemical Monthly 142(4): 375-384.

Palaniappan, P.R. \& Karthikeyan, S. 2009. Bioaccumulation and depuration of chromium in the selected organs and whole body tissues of freshwater fish Cirrhinus mrigala individually and in binary solutions with nickel. Journal of Environmental Sciences 21(2): 229-236.

Rana, A., Gallo, K., Godowski, P., Hirai, S.I., Ohno, S., Zon, L., Kyriakis, J.M. \& Avruch, J. 1996. The mixed lineage kinase SPRK phosphorylates and activates the stress-activated protein kinase activator, SEK-1. Journal of Biological Chemistry 271(32): 19025-19028.

Rejomon, G., Nair, M. \& Joseph, T. 2010. Trace metal dynamics in fishes from the southwest coast of India. Environmental Monitoring and Assessment 167(1): 243-255.

Ressurreição, M., Rollinson, D., Emery, A.M. \& Walker, A.J. 2011. A role for p38 mitogen-activated protein kinase in early post-embryonic development of Schistosoma mansoni. Molecular and Biochemical Parasitology 180(1): 51-55.

Rios-Barrera, D., Vega-Segura,A., Thibert, V., Rodríguez-Zavala, J.S. \& Torres-Marquez, M.E. 2008. p38 MAPK as a signal transduction component of heavy metals stress in Euglena gracilis. Archives of Microbiology 191(1): 47-54.

Sahu, S.N., Lewis, J., Patel, I., Bozdag, S., Lee, J.H., Sprando, R. \& Cinar, H.N. 2013. Genomic analysis of stress response against arsenic in Caenorhabditis elegans. PLOS ONE 8(7): e66431.

Saliu, J.K. \& Bawa-Allah, K.A. 2012. Toxicological effects of lead and zinc on the antioxidant enzyme activities of post juvenile Clarias gariepinus. Resources and Environment 2(1): 21-26.

Sevcikova, M., Modra, H., Slaninova, A. \& Svobodova, Z. 2011. Metals as a cause of oxidative stress in fish: A review. Vet. Med. 56(11): 537-546.
Stohs, S.J. \& Bagchi, D. 1995. Oxidative mechanisms in the toxicity of metal ions. Free Radical Biology and Medicine 18(2): 321-336.

Suratman, S., Tahir, N.M., Yeow, L.C. \& Rashid, S.R.A. 2006. Kesan monsun terhadap kualiti air di Lembangan Sungai Besut, Terengganu. Malaysian Journal of Analytical Sciences 10(1): 143-148.

Sures, B., Siddall, R. \& Taraschewski, H. 1999. Parasites as accumulation indicators of heavy metal pollution. Parasitology Today 15(1): 16-21.

Tekaya, N., Saiapina, O., Ben Ouada, H., Lagarde, F., Ben Ouada, H. \& Jaffrezic-Renault, N. 2013. Ultra-sensitive conductometric detection of heavy metals based on inhibition of alkaline phosphatase activity from Arthrospira platensis. Bioelectrochemistry 90: 24-29.

Valko, M., Morris, H. \& Cronin, M. 2005. Metals, toxicity and oxidative stress. Current Medicinal Chemistry 12(10): 1161-1208.

Ventura-Lima, J., Bogo, M.R. \& Monserrat, J.M. 2011 . Arsenic toxicity in mammals and aquatic animals: A comparative biochemical approach. Ecotoxicology and Environmental Safety 74(3): 211-218.

Wang, S., Tang, M., Pei, B., Xiao, X., Wang, J., Hang, H. \& Wu, L. 2008. Cadmium-induced germline apoptosis in Caenorhabditis elegans: The roles of HUS1, p53, and MAPK signaling pathways. Toxicological Sciences 102(2): 345-351.

Wilhelm, D., Bender, K., Knebel, A. \& Angel, P. 1997. The level of intracellular glutathione is a key regulator for the induction of stress-activated signal transduction pathways including Jun N-terminal protein kinases and p38 kinase by alkylating agents. Molecular and Cellular Biology 17(8): 4792-800.

Zimmermann, S., Sures, B. \& Taraschewski, H. 1999. Experimental studies on lead accumulation in the eelspecific endoparasites Anguillicola crassus (Nematoda) and Paratenuisentis ambiguus (Acanthocephala) as compared with their host, Anguilla anguilla. Archives of Environmental Contamination and Toxicology 37(2): 190-195.

Nurul Huda Abd Kadir \& Mohd Fauzi Mahmud

School of Fundamental Science

Universiti Malaysia Terengganu

21030 Kuala Nerus, Terengganu Darul Iman

Malaysia

Mohamad Khairi Mohd Zainol

School of Science and Food Technology

Universiti Malaysia Terengganu

21030 Kuala Nerus, Terengganu Darul Iman

Malaysia

Nurul Huda Abd Kadir, Mastura Abd Malek \&

Faizah Shaharom Harrison

Institute of Tropical Aquaculture (AQUATROP)

Universiti Malaysia Terengganu

21030 Kuala Nerus, Terengganu Darul Iman

Malaysia

Faizah Shaharom Harrison

School of Fisheries and Aquaculture

Universiti Malaysia Terengganu

21030 Kuala Nerus, Terengganu Darul Iman

Malaysia 
Mastura Abd Malek

Institute of Medical Molecular Biotechnoloy (IMMB)

Faculty of Medicine, Universiti Teknologi MARA

Selangor Branch, Sungai Buloh Campus

47000 Sungai Buloh, Selangor Darul Ehsan

Malaysia
*Corresponding author; email: nurulhuda@umt.edu.my

Received: 21 November 2017

Accepted: 19 Februari 2018 